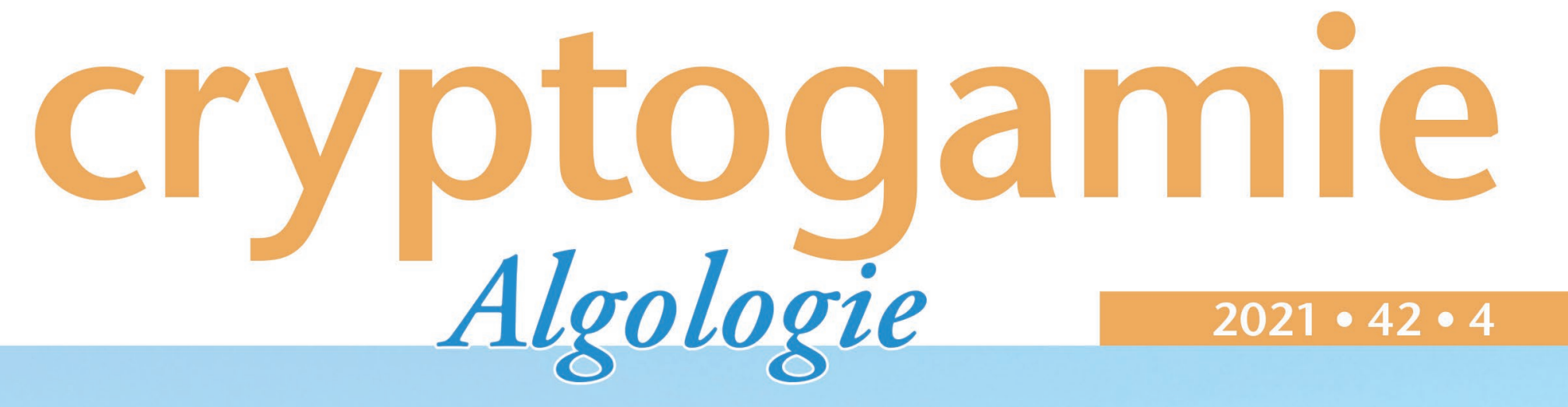

Merphologjtcal ansel phylogenetic elata confírss the identity of Prosioles fluvitutilis (Prasiolales, Trebousitopinyceae) from glacler stireams

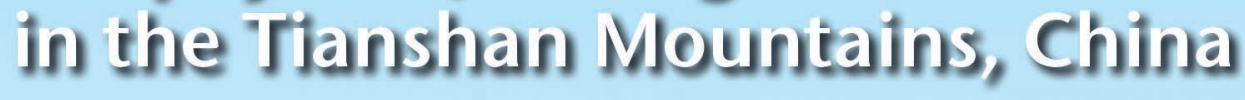

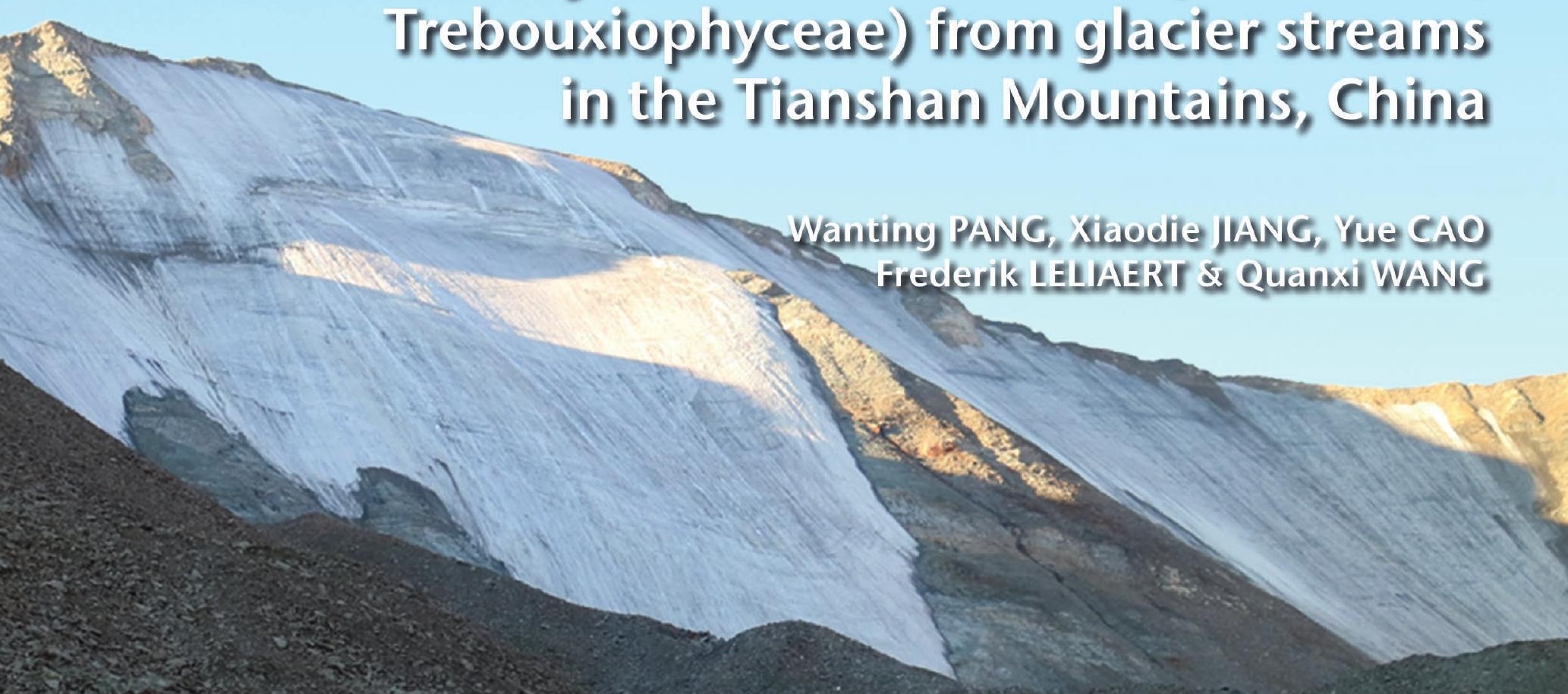


DiRECTEUR DE LA PUBLICATION / PUBLICATION DIRECTOR: Bruno DAVID

Président du Muséum national d'Histoire naturelle

RÉDACTRICE EN CHEF / EDITOR-IN-CHIEF : Line LE GALL

Muséum national d'Histoire naturelle

ASSISTANTE DE RÉDACTION / AsSISTANT EDITOR : Marianne SALAÜN (algo@cryptogamie.com)

MISE EN PAGE / PAGE LAYOUt : Marianne SALAÜN

RÉDACTEURS ASSOCIÉs / AsSOCIATE EDITORS

Ecoevolutionary dynamics of algae in a changing world

Stacy KRUEGER-HADFIELD

Department of Biology, University of Alabama, 1300 University Blvd, Birmingham, AL 35294 (United States)

Jana KULICHOVA

Department of Botany, Charles University, Prague (Czech Republic)

Cecilia TOTTI

Dipartimento di Scienze della Vita e dell'Ambiente, Università Politecnica delle Marche, Via Brecce Bianche, 60131 Ancona (Italy)

Phylogenetic systematics, species delimitation \& genetics of speciation

Sylvain FAUGERON

UMI3614 Evolutionary Biology and Ecology of Algae, Departamento de Ecología, Facultad de Ciencias Biologicas,

Pontificia Universidad Catolica de Chile, Av. Bernardo O’Higgins 340, Santiago (Chile)

Marie-Laure GUILLEMIN

Instituto de Ciencias Ambientales y Evolutivas, Universidad Austral de Chile, Valdivia (Chile)

Diana SARNO

Department of Integrative Marine Ecology, Stazione Zoologica Anton Dohrn, Villa Comunale, 80121 Napoli (Italy)

Comparative evolutionary genomics of algae

Nicolas BLOUIN

Department of Molecular Biology, University of Wyoming, Dept. 3944, 1000 E University Ave, Laramie, WY 82071 (United States)

Heroen VERBRUGGEN

School of BioSciences, University of Melbourne, Victoria, 3010 (Australia)

Algal physiology \& photosynthesis

Janet KÜBLER

California State University Northridge, Department of Biology, California State University, Northridge, CA 91330-8303 (United States)

Prokaryotic algae

Nico SALMASO

IASMA Research and Innovation Centre, Fondazione Mach-Istituto Agrario di S. Michele all'Adige, Limnology and River Ecology,

Via E. Mach, 1, 38010 San Michele all'Adige, Trento (Italy)

Vitor VASCONCELOS

Faculdade de Ciências da Universidade do Porto and CIIMAR, Rua do Campo Alegre, s/n, 4169-007 Porto (Portugal)

COUVERTURE / COVER:

Extraits d'éléments de la Figure 1 / Extracts of the Figure 1

Cryptogamie, Algologie est indexé dans / Cryptogamie, Algologie is indexed in:

- Aquatic Sciences \& Fisheries Abstracts Part I.

- Biological Abstracts

- Chemical Abstracts

- Current Contents

- Marine Science Contents Tables (FAO)

- Science Citation Index

- Publications bibliographiques du CNRS (Pascal).

Cryptogamie, Algologie est distribué en version électronique par / Cryptogamie, Algologie is distributed electronically by:

- BioOne ${ }^{\circledR}$ (http://www.bioone.org/loi/crya)

Cryptogamie, Algologie est une revue en flux continu publiée par les Publications scientifiques du Muséum, Paris

Cryptogamie, Algologie is a fast track journal published by the Museum Science Press, Paris

Les Publications scientifiques du Muséum publient aussi / The Museum Science Press also publishes: Adansonia, Geodiversitas, Zoosystema, Anthropozoologica, European Journal of Taxonomy, Naturae, Comptes Rendus Palévol, Cryptogamie sous-sections Bryologie, Mycologie.

Diffusion - Publications scientifiques Muséum national d'Histoire naturelle

CP $41-57$ rue Cuvier F-75231 Paris cedex 05 (France)

Tél. : 33 (0)1 40794805 / Fax: 33 (0)1 40793840

diff.pub@mnhn.fr / http://sciencepress.mnhn.fr

(c) Publications scientifiques du Muséum national d'Histoire naturelle, Paris, 2021

ISSN (imprimé / print): 0181-1568 / ISSN (électronique / electronic): 1776-0984 


\title{
Morphological and phylogenetic data confirm the identity of Prasiola fluviatilis (Prasiolales, Trebouxiophyceae) from glacier streams in the Tianshan Mountains, China
}

\author{
Wanting PANG \\ College of Life Sciences, Shanghai Normal University, 200234 Shanghai (China) \\ and Meise Botanic Garden, 1860 Meise (Belgium) \\ Xiaodie JIANG \\ Yue CAO \\ College of Life Sciences, Shanghai Normal University, 200234 Shanghai (China) \\ Frederik LELIAERT \\ Meise Botanic Garden, 1860 Meise (Belgium) \\ Quanxi WANG \\ College of Life Sciences, Shanghai Normal University, 200234 Shanghai (China) \\ wangqx@shnu.edu.cn (corrresponding author)
}

Submitted on 6 August 2020 | Accepted on 15 January 2021 | Published on 31 March 2021

\footnotetext{
KEY WORDS

Biogeography,

Trebouxiophina, ophyceae,

phylogeny,

Prasiola fluviatilis.
}

MOTS CLÉS

Biogéographie,

Trebouxiophyceae,

phylogénie,

Prasiola fluviatilis.
Pang W., Jiang X., Cao Y., Leliaert F. \& Wang Q. 2021. - Morphological and phylogenetic data confirm the identity of Prasiola fluviatilis (Prasiolales, Trebouxiophyceae) from glacier streams in the Tianshan Mountains, China. Cryptogamie, Algologie 42 (4): 47-58. https://doi.org/10.5252/cryptogamie-algologie2021v42a4. http://cryptogamie.com/algologie/42/4

\section{ABSTRACT}

The green alga Prasiola fluviatilis (Sommerfelt) Areschoug ex Lagerstedt occurs in cold lotic environments. The species has a mainly circumarctic distribution, but has also been reported from glacier areas in lower latitude regions in both hemispheres. It was reported from China on a single occasion in the first half of the $20^{\text {th }}$ century, but without description, illustrations or voucher specimens the identity of this record cannot be verified. Here we confirm the presence of P. fluviatilis in the Tianshan Mountains, Xinjiang Province, China based on morphological features, habitat characteristics, and plastid $r b c \mathrm{~L}$ and tufA gene sequences. The biogeographic distribution of P. fluviatilis and its phylogenetic relationship with other terrestrial and freshwater Prasiola species are discussed.

\section{RÉSUMÉ}

Des données morphologiques et phylogénétiques confirment l'identité de Prasiola fluviatilis (Prasiolales, Trebouxiophyceae) dans les cours d'eau glaciaires des montagnes Tianshan, en Chine.

L'algue verte Prasiola fluviatilis (Sommerfelt) Areschoug ex Lagerstedt est présente dans les milieux lotiques froids. L'espèce a une distribution principalement circumarctique, mais a également été signalée dans les zones glaciaires des régions de basse latitude dans les deux hémisphères. Elle a été rapportée en Chine à une seule occasion dans la première moitié du 20e siècle, mais sans description, illustration ou spécimen de référence, l'identité de cette observation ne peut être vérifiée. Nous confirmons ici la présence de $P$. fluviatilis dans les monts Tianshan, dans la province du Xinjiang, en Chine, sur la base des caractéristiques morphologiques, les caractéristiques de l'habitat et les séquences des gènes du plaste $r b c \mathrm{~L}$ et $t u f \mathrm{~A}$. La distribution biogéographique de $P$. fluviatilis et sa relation phylogénétique avec d'autres espèces de Prasiola terrestres et d'eau douce sont discutées. 


\section{INTRODUCTION}

The green algal genus Prasiola Meneghini (1838) is characterized by monostromatic laminar thalli, and vegetative cells with stellate or lobed chloroplasts containing a single pyrenoid. It is the most species-rich genus in the trebouxiophycean order Prasiolales Schaffner, including about 35 species distributed in marine, freshwater and terrestrial habitats, mainly in temperate to arctic regions with some species also occurring in lower latitude regions (Børgesen 1946; Waern 1952; Ettl \& Gärtner 1995; Kováčik \& Pereira 2001; Naw \& Hara 2002; Rindi \& Guiry 2004; Rodriguez \& Jiménez 2005; Rodriguez et al. 2007; Guiry \& Guiry 2020).

Traditionally, the taxonomy of the genus has relied on a number of diagnostic morphological characters to delineate species, including shape and size of the blade, presence/absence of a holdfast, structure of the stipe, cell size, life history, and type of habitat (Knebel 1935; Printz 1964; Kornmann \& Sahling 1974; Ettl \& Gärtner 1995; John 2002; Rindi 2007). However, many Prasiola species exhibit extensive morphological plasticity under different environmental conditions or developmental stages (Neustupa 1998; Rindi et al. 1999, 2007; Kováčik \& Pereira 2001; Rindi 2010). In addition, cryptic species diversity has been demonstrated in the genus (Moniz et al. 2012b). This combination of plasticity and cryptic diversity makes species identification difficult based on morphology alone. It has therefore been recommended that a combination of morphological, ecological and molecular data should be used for reliable species circumscription and identification in Prasiola (Rindi et al. 2007; Heesch et al. 2012; Heesch et al. 2016; Klochkova et al. 2017). Molecular phylogenetic studies and DNA taxonomy in Prasiola has been facilitated by an increasing amount of available DNA sequence data (Sherwood et al. 2000; Naw \& Hara 2002; Rindi et al. 2004, 2007; Saunders \& Kucera 2010; Heesch et al. 2012; Moniz et al. 2012a, b; Kim et al. 2015; Klochkova et al. 2017).

Species of Prasiola occur in various environments, including fast flowing freshwater streams, humid rocks, barks or soil, and high intertidal and adjacent splash zone habitats, often associated with high inputs of organic nitrogen (Rindi et al. 1999; Rindi \& Guiry 2004; Sutherland et al. 2016). In addition, some species engage in symbiotic relationships with lichens (Garrido-Benavent et al. 2017a, b). Although several species can be categorized as strictly freshwater/terrestrial or marine, some species tolerate a wide range of salinities and may occur in both environments (Rindi 2007). About 14 species of Prasiola occur in freshwater or terrestrial environments. Remarkably, eleven of these have been described from Asia (Guiry \& Guiry 2020). Unfortunately, there are relatively few molecular phylogenetic data of Asian freshwater species compared to other regions (Naw \& Hara 2002; Moniz et al. 2012b, 2014; Kim et al. 2015).

Prasiola fluviatilis (Sommerfelt) Areschoug ex Lagerstedt (1869) was originally described by Sommerfelt (1828) from running water in the mountains of Lerdalselfven, Norway. The linear thallus shape separated it from the other freshwater
Prasiola species (Lagerstedt 1869; Knebel 1935; Hamilton \& Edlund 1994). The species has a mainly circumarctic distribution, but has also been reported from cold lotic environments in lower latitude regions in both hemispheres. More specifically, it has been recorded from Europe (Rejment-Grochowska 1952), North America (Setchell \& Gardner 1903; Taylor 1928; Kobayasi 1967), the Arctic region (Hamilton \& Edlund, 1994; Sherwood et al. 2000; Matuła et al. 2007), Asia (Borge 1934; Barinova et al. 2015; Barinova \& Niyatbecove 2018), sub-Antarctica (Eaton 2012), and South America (McClintic et al. 2003). In Asia the species has so far only been observed in the Tianshan Mountains, Xinjiang Province, China (Borge 1934), and in neighboring Tajikistan (Barinova et al. 2015; Barinova \& Niyatbekov 2018). However, no descriptions or illustrations were provided by Borge, nor are there any historical voucher specimens available for China. Globally, the only molecular data of $P$. fluviatilis are available from material of Canada (Sherwood et al. 2000) and Svalbard, Norway (Heesch et al. 2016).

In this study, specimens of Prasiola were collected in the Tianshan Mountains from similar habitats where P. fluviatilis was originally found by Borge (1934). Detailed morphological features, habitat characteristics, and plastid $r b c \mathrm{~L}$ and tufA gene sequences are presented and confirm that the geographical range of $P$. fluviatilis extends into China.

\section{MATERIAL AND METHODS}

\section{COLLECTION OF SAMPLES AND MORPHOLOGICAL OBSERVATION}

Samples were collected in August 2017 from Tianshan Moun-

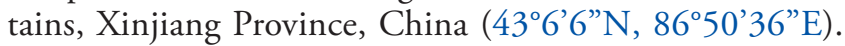
Populations of $P$. fluviatilis were found tightly adherent to rocks and stones in streams (3570 $\mathrm{m}$ a.s.l.) under a glacier (Fig. 1) with water temperature $0.4^{\circ} \mathrm{C}, \mathrm{pH} 7.5$, and slow velocity. Specimens were preserved in $4 \%$ formalin for morphological observations, and dried in silica gel for DNA extraction. Morphological observations were performed using a Zeiss Imager A2 light microscope, and photographs were taken with an Axiocam 506 color mounted on the microscope. The samples (XJ20170806-1, XJ20170806-2, XJ20170806-3, XJ201708064) are deposited in the herbarium of the Laboratory of Algae and Environment, Biology Department, Shanghai Normal University (SHTU), Shanghai, China.

\section{DNA EXTRACTION, PCR AMPLIFICATION \\ AND AUTOMATED SEQUENCING}

The silica dried specimens were ground using liquid nitrogen, followed by DNA extraction using a NucleoSpin Plant II kit (Macherey-Nagel, Düren, Germany), following the manufacturer's protocol. We amplified and sequenced the plastid $r b c \mathrm{~L}$ (1036 bases) and tufA (821 bases) genes from two specimens. Polymerase chain reactions (PCR) were performed using published primers: the amplification of the $r b c$ L gene was carried out using primers PF2 and PR2 (Rindi et al. 2004), and that of the tufA gene was carried out using primers tufGF 4 and 

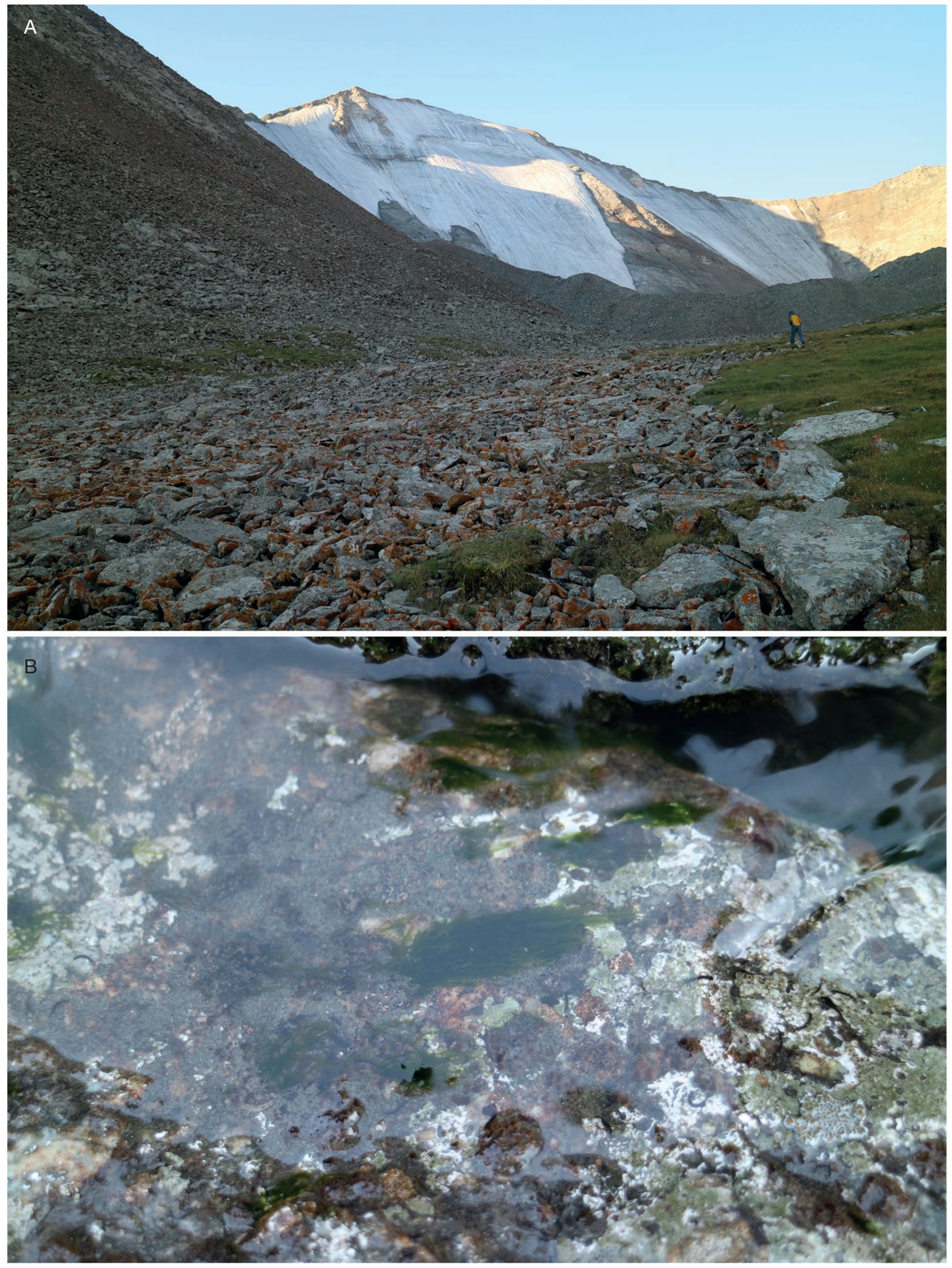

FIG. 1. - Habitat of Prasiola fluviatilis (Sommerfelt) Areschoug ex Lagerstedt: A, streams under a glacier; B, population of $P$. fluviatilis. 
TABLE 1. - Morphological data of Prasiola fluviatilis (Sommerfelt) Areschoug ex Lagerstedt from different sites. Note: the data of $P$. fluviatilis from Bolivia was measured from the figures in McClintic et al. (2003).

\begin{tabular}{|c|c|c|c|c|}
\hline Site & $\begin{array}{l}\text { Size of } \\
\text { frond }(\mathrm{cm})\end{array}$ & $\begin{array}{l}\text { Thickness } \\
\quad(\mu \mathrm{m})\end{array}$ & $\begin{array}{c}\text { sCell size } \\
(\mu \mathrm{m})\end{array}$ & Reference \\
\hline $\begin{array}{l}\text { Tianshan } \\
\text { Mountains, } \\
\text { China }\end{array}$ & $\begin{array}{r}0.2-1.4 \times \\
1.0-8.0\end{array}$ & - & $3.7-12.1$ & This paper \\
\hline $\begin{array}{l}\text { Ellesmere Island, } \\
\text { Canada }\end{array}$ & $\begin{array}{c}0.02-0.3 \times \\
4.5-9.5\end{array}$ & $2.0-8.8$ & $\begin{array}{l}3.2-7.6 \times \\
3.0-12.6\end{array}$ & $\begin{array}{l}\text { Hamilton } \\
\text { (1994) }\end{array}$ \\
\hline Svalbard, Norway & $\begin{array}{l}\text { Up to } 1.5 \times \\
0.2\end{array}$ & $15.0-18.0$ & $2.5-10$ & Heesch (2016) \\
\hline Europe & $\begin{array}{l}\text { Up to } 11.0 \times \\
2.0\end{array}$ & 8.0-19.0 & - & Knebel (1935) \\
\hline Bolivia & 1.0 & - & $5.0-8.8$ & $\begin{array}{l}\text { McClintic } \\
\text { et al. (2003) }\end{array}$ \\
\hline
\end{tabular}

tufAR (Saunders \& Kucera 2010). PCR's were conducted in $50 \mu \mathrm{L}$ volumes containing $1.0 \mu \mathrm{L}$ genomic DNA, $1.0 \mu \mathrm{L}$ of each primer $(10 \mathrm{mM}), 25 \mu \mathrm{L} 2 \mathrm{xEasy}$ Taq ${ }^{\circ}$ PCR SuperMix (all from TransGen Biotech, China), and $22 \mu \mathrm{L} \mathrm{ddH} 2 \mathrm{O}$, as described by Rindi et al. (2004). The PCR reaction profile of both genes was as follows: initial denaturation at $94^{\circ} \mathrm{C}$ for 5 min, 35 cycles of $94^{\circ} \mathrm{C}$ for $30 \mathrm{~s}, 58^{\circ} \mathrm{C}$ for $30 \mathrm{~s}, 72^{\circ} \mathrm{C}$ for $1 \mathrm{~min}$, and the final extension at $72^{\circ} \mathrm{C}$ for $10 \mathrm{~min}$. The PCR products were sent to BGI Tech Corporation (Shanghai, China) for sequencing in an ABI 3730XL sequencer. Forward and reverse sequences were assembled using SeqMan, and submitted to GenBank (accession no. MT846163 for $r b c \mathrm{~L}$ and MT846164 for tufA).

\section{SEQUENCE ALIGNMENT AND PHYLOGENETIC RECONSTRUCTION}

An initial identification of $r b c \mathrm{~L}$ and tufA sequence was performed using a similarity search (megablast). All $r b c \mathrm{~L}$ and tufA sequences of Prasiola in GenBank were exhaustively searched. Very short sequences ( $<200 \mathrm{bp}$ ) were excluded from the alignment. Based on the result of Neighbor-joining phylogenetic analyses, a selection of sequences was made to be retained by keeping one or a few sequences per species and excluding identical or near identical sequences. The final sequences of the genera Prasiola, Prasiolopsis Vischer and Rosenvingiella Silva (the latter two were used as outgroup) (listed in Appendices 1; 2) were aligned using ClustalW (Thompson et al. 1997) in BioEdit v.7.0.9 (Hall 1999). Sequence alignments are available to download from the open-access repository Zenodo: https:// doi.org/10.5281/zenodo.4271930. Uncorrected pairwise (p) distances were calculated using MEGA 6.0 (Appendix 3). The $r b c \mathrm{~L}$ alignment included 41 Prasiola, Prasiolopsis and Rosenvingiella sequences, to yield a final alignment of 896 bases. The tufA gene alignment included 39 Prasiola, Prasiolopsis and Rosenvingiella sequences, to yield a final alignment of 531 bases. The optimal substitution model for each marker was generated using Modeltest 3.7 with related results listed in Appendix 4 (Posada \& Buckley 2004). Maximum likelihood (ML) phylogenetic trees were generated using PHYML v.3.0 using default settings and 1000 bootstrap replicates (Felsen- stein 1981; Guindon \& Gascuel 2003). Bayesian inference (BI) analyses were performed using MrBayes version 3.1.2 (Ronquist \& Huelsenbeck 2003). A Markov chain Monte Carlo (MCMC) algorithm running three hot Markov chains and one cold Markov chain was used to estimate the posterior probability of phylogenetic trees. The Markov chains were started from a random tree and run for 2000000 generations, sampling every 1000 generations for a total of 2000 samples for each run. Figtree v.1.4.2 was used to edit all resulting phylogenetic trees.

\section{RESULT}

\section{MoRPHOLOGY}

Thalli occurred in tufts of at least seven ribbon-like monostromatic blades, $1.0-8.0 \mathrm{~cm}$ long and $0.2-1.4 \mathrm{~cm}$ wide (Fig. 2A, B; Table 1). Vegetative cells were quadrat, rectangular or elliptical in surface view, and arranged in many longitudinal rows (Fig. 2C, D). Cells in the lower part of the blade were elongated, 6.3-13.2 $\mu \mathrm{m}$ long and 2.0-5.3 $\mu \mathrm{m}$ wide (Fig. 2E, F), and produced rhizoids that attached to the substrate. Cells in the upper portion of the thallus were 3.7-12.1 $\mu \mathrm{m}$ in diameter, round to square in shape, and arranged more or less in groups of four cells; clear areolae and thickened longitudinal lines were present between these groups (Fig. 2G). Uniseriate filaments were also observed (Fig. $2 \mathrm{H}$ ). Reproduction was not observed.

\section{Phylogenetic ANALYSES}

$R b c \mathrm{~L}$ and tufA sequences from the different specimens were found to be identical, so only one new sequence of each marker was included in the analyses.

$\mathrm{ML}$ and $\mathrm{BI}$ analyses of the $r b c \mathrm{~L}$ alignment yielded similar tree topologies. Information on estimated substitution models and base frequencies is provided in Appendix 4. The $r b c \mathrm{~L}$ analysis (Fig. 3) showed that our sequences formed a clade with P. fluviatilis sequences from Canada and Norway with maximal statistical support (ML bootstrap values / BI posterior probabilities: 100/1.00). This clade was sister to P. calophylla (Carmichael ex Greville) Kützing (63/0.90). The pairwise distance between our strain and the P. fluviatilis sequences from Canada and Norway was both 0.003 , corresponding to three base pair differences.

Similarly to the $r b c \mathrm{~L}$ analyses, our tufA sequences of $P$. $f l u$ viatilis were sister to P. calophylla (78/0.99) (Fig. 4). Since no other tufA sequences of P. fluviatilis are available on GenBank, no further conclusions could be made based on the tufA analyses.

\section{DISCUSSION}

Prasiola fluviatilis, a species that has been recorded mainly from Arctic regions of Europe and North America, has also been reported from cold lotic environments in other regions, including China and Tajikistan (Borge 1934; Barinova et al. 

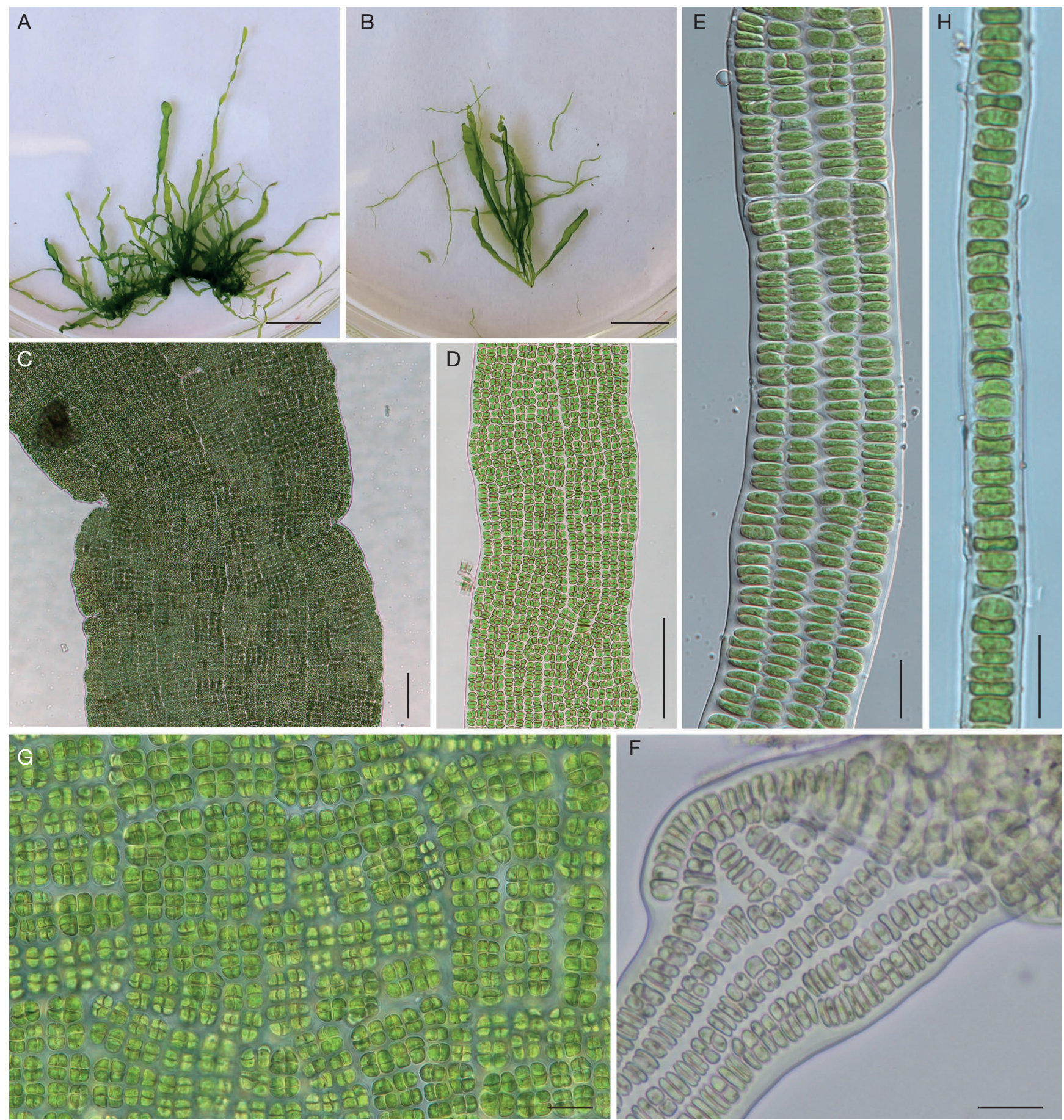

FIG. 2. - Morphology of Prasiola fluviatilis (Sommerfelt) Areschoug ex Lagerstedt: A, B, thalli; C, D, vegetative cells; E, F, cells in the lower part of the blade; G, cells in the upper portion of the thallus; $\mathbf{H}$, uniseriate branches. Scale bars: A, B, $1 \mathrm{~cm} ; \mathrm{C}, \mathrm{D}, 100 \mu \mathrm{m} ; \mathrm{E}-\mathrm{H}, 20 \mu \mathrm{m}$.

2015; Barinova \& Niyatbecove 2018). However, no morphological information was provided for these Asian records. In addition, no molecular data were available to date for Asian representatives of this species, and as a result their identity as well as their extended geographical range in Asia remained uncertain. We found $P$. fluviatilis in the same region where it was originally collected by Borge (1934), and confirmed its identity based on habitat, morphological, and plastid gene data.
We applied two markers in our phylogenetic analyses, $r b c \mathrm{~L}$ and tufA. Both are frequently used for phylogenetic inference, and species delimitation and identification in the genus (Kim et al. 2015; Heesch et al. 2016; Sutherland et al. 2016; Klochkova et al. 2017). TufA has been proposed as a good candidate marker for DNA barcoding in freshwater and marine green algae because of its high universality, relatively low contamination rate, apparent lack of introns, and high 


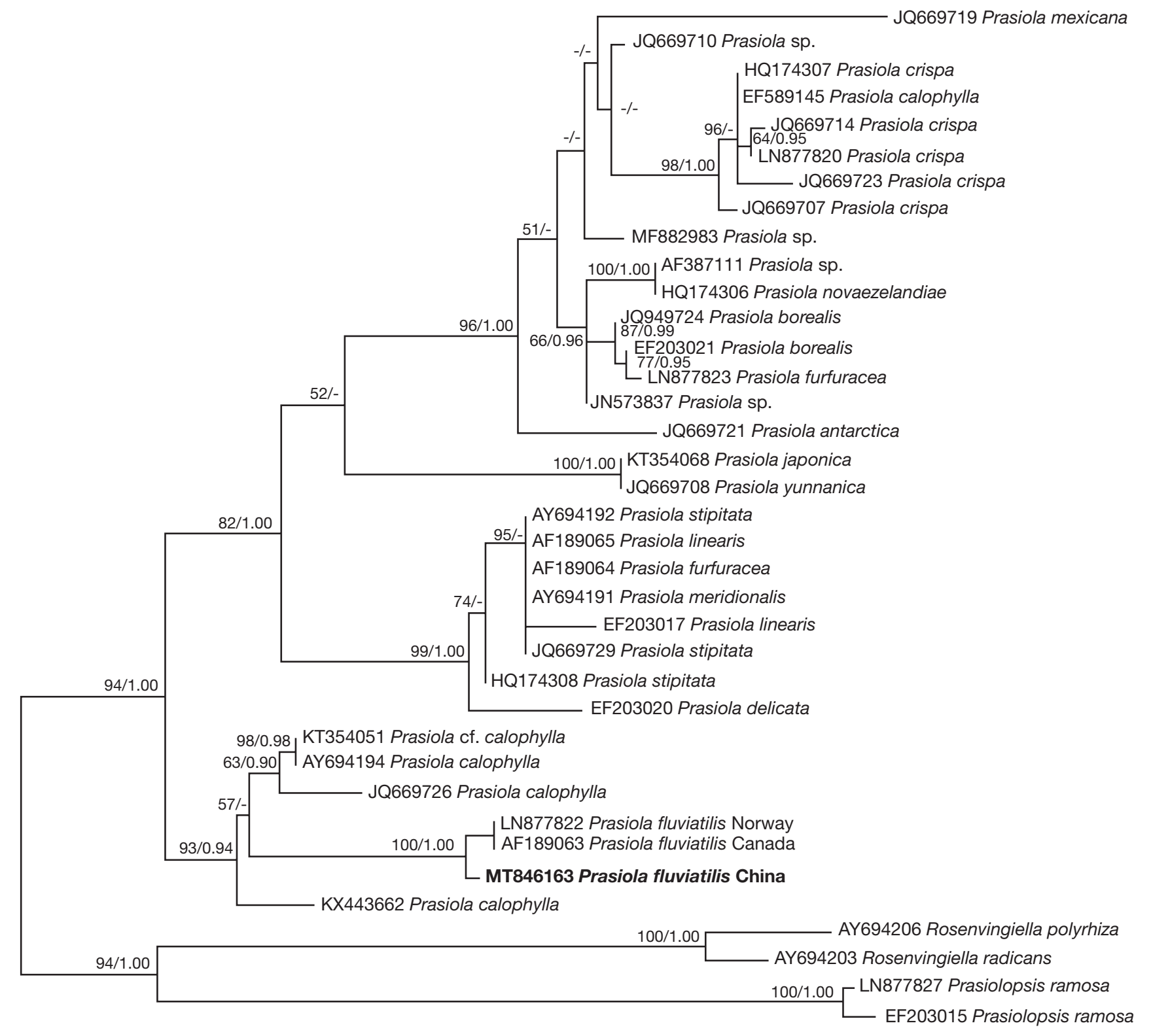

FIG. 3. - Phylogenetic position of Chinese Prasiola fluviatilis (Sommerfelt) Areschoug ex Lagerstedt inferred from maximum likelihood analysis of the rbcL gene. Bootstrap values and Bayesian posterior probabilities are indicated at the branches. Only bootstrap values above $50 \%$ and posterior probabilities above 0.9 are shown.

species discrimination power (Hall et al. 2010; Saunders \& Kucera 2010; Moniz et al. 2014). This gene has great potential as a marker for phylogenetic inference at low taxonomic levels in the Trebouxiophyceae, and was able to separate Prasiola species for which $S S U$ and $r b c \mathrm{~L}$ sequences were identical or nearly identical (Moniz et al. 2014).

Our $r b c \mathrm{~L}$ and tufA phylogenies both confirmed a sister relationship between P. Aluviatilis and P. calophylla (Carmichael ex Greville) Kützing, and the two species were separated by relatively long and well supported branches in both analyses (Figs 3; 4). P. calophylla is a terrestrial species with linear blades, which is tolerant of sea spray but never grows submerged in seawater (Rindi 2007; Rindi et al. 2007; Moniz et al. 2012a, b; Kim et al. 2015; Heesch et al. 2016). Our specimens of P. Aluviatilis were found in streams under a glacier which formed only seasonally running cold water. This situation is similar to environments in Svalbard and Ellesmere Island, the only two localities where the presence of $P$. fluviatilis has been confirmed by sequence data. Other freshwater Prasiola species, such as P. mexicana Agardh, P. nevadensis Setchell \& Gardner, P. elongata Hu, P. japonica Yatabe, P. formosana Okada, $P$. tibetica Jao, and P. yunnanica Jao are exclusively freshwater organisms, which occur completely submerged in permanent streams (Setchell \& Gardner 1920; Jao 1947; Printz 1964; 


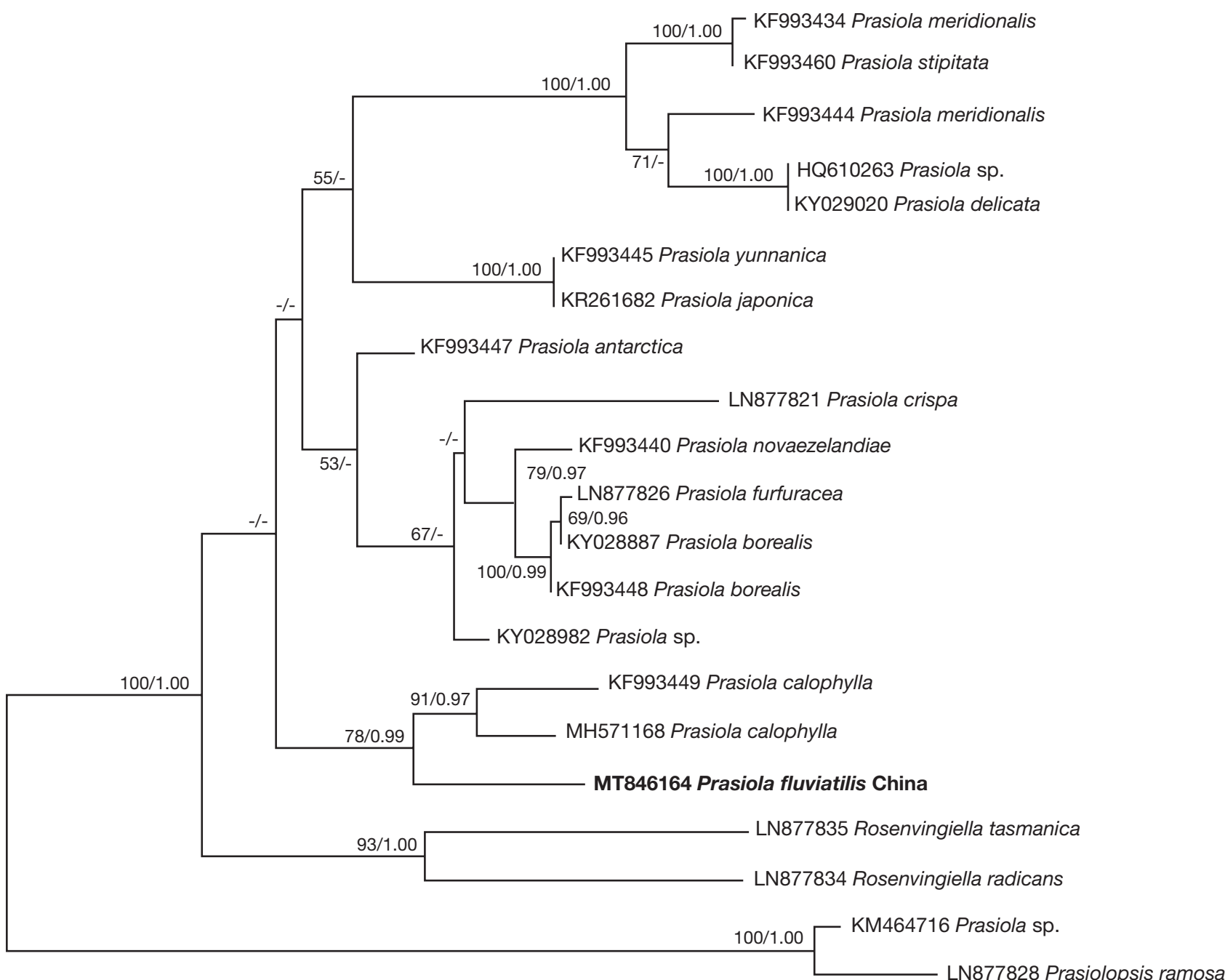

FIG. 4. - Phylogenetic position of Chinese Prasiola fluviatilis (Sommerfelt) Areschoug ex Lagerstedt inferred from maximum likelihood analysis and Bayesian analyses of the tufA gene. Bootstrap values and Bayesian posterior probabilities are indicated at the branches. Only bootstrap values above $50 \%$ and posterior probabilities above 0.9 are shown.

Vazquez \& Uriza 2003; Hu \& Wei 2006). Our phylogenetic analyses suggest that linear thallus shape, as well as habitat type in $P$. calophylla and $P$. fluviatilis, may be phylogenetically conserved, consistent with the idea of Rindi et al. (2007). Phylogenetic analysis shows that $P$. yunnanica (a species that was proposed as a synonym of $P$. japonica and $P$. formosana var. coreana Okada based on a plastid gene phylogeny and habitat characteristics by Kim et al. (2015)) is unrelated to P. fluviatilis. Sequence data for other Asian freshwater Prasiola species are lacking. Globally, 14 freshwater Prasiola species are accepted taxonomically, but molecular data of only four species, P. japonica, P. fluviatilis, P. glacialis Moniz, Rindi, Novis, Broady \& Guiry and P. mexicana, are available. More data from different species and different strains within species are needed to unravel the evolutionary history of freshwater and terrestrial Prasiola species.

The $r b c \mathrm{~L}$ sequence of our strain only showed 3 bp differences from those from Svalbard and Canada, and the latter two sequences are identical (Hamilton \& Edlund 1994; Heesch et al. 2016). The habitats of these three collection sites are very similar. Although $P$. fluviatilis is morphologically well defined by its narrow ribbon-like blades, which sets it apart from all other freshwater species, it remains to be confirmed based on DNA sequence data if strains from other regions actually belong to the same species. Based on our observations and previous descriptions of P. fluviatilis, thallus and cell sizes can vary substantially among individuals from different sites (Knebel 1935; Hamilton \& Edlund 1994; McClintic et al. 2003; Heesch et al. 2016) (Table 1). In general, species of Prasiola show extensive morphological plasticity, as has been shown in marine species (Rindi et al. 2004, 2007; Rindi 2010), and this is likely also true for freshwater and terrestrial Prasiola species (Rindi et al. 2004; Kim et al. 2015). P. velutina (Lyngbye) Trevisan shares a similar habitat with $P$. fluviatilis and also has a circumarctic distribution. Although the species has uniseriate filaments as dominant growth habit (Lokhorst \& 


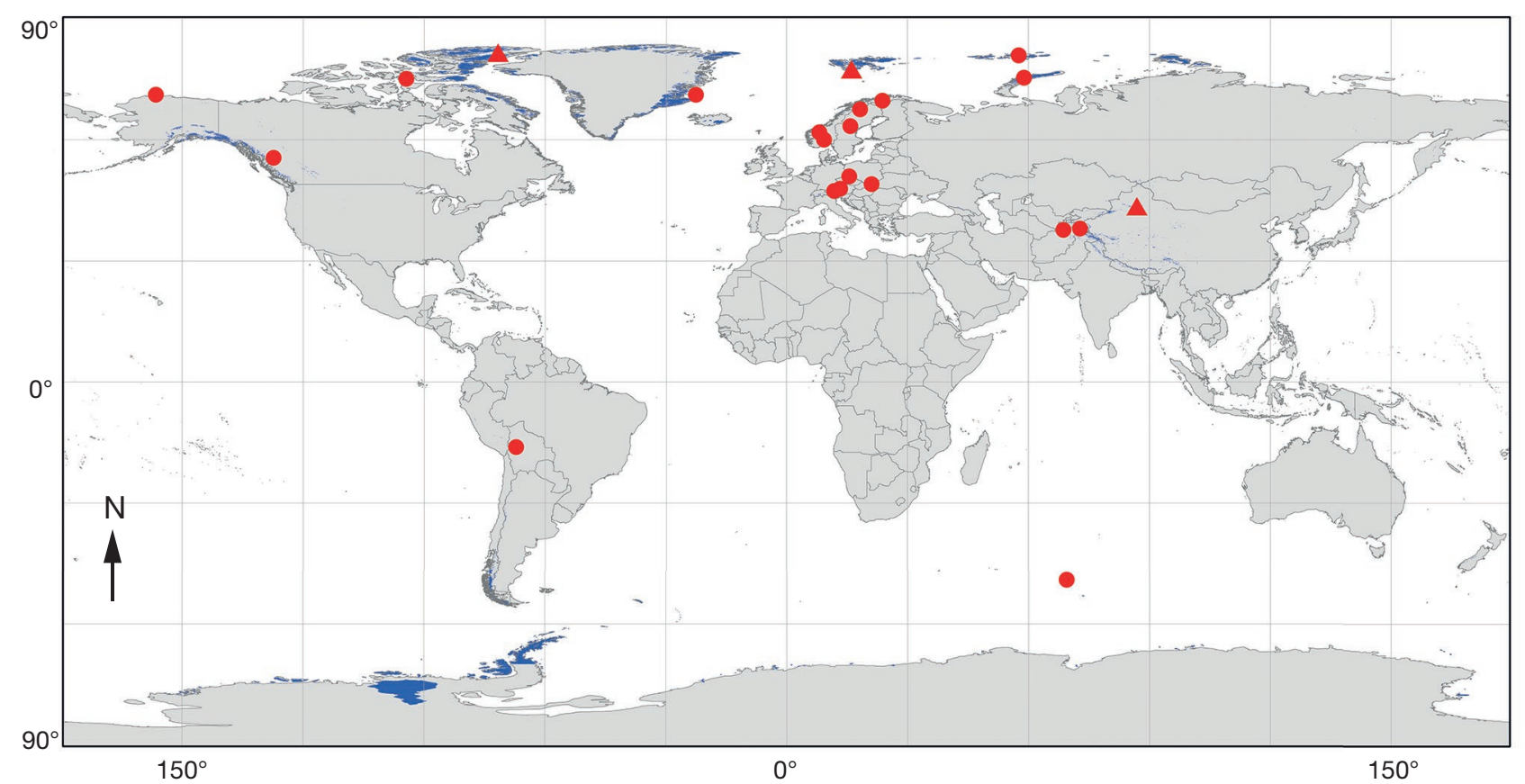

FIG. 5. - Global distribution of Prasiola fluviatilis (Sommerfelt) Areschoug ex Lagerstedt (blue: glacier area [GLIMS and NSIDC 2005, updated 2019]; 9 , occurrence records based on morphology; $\boldsymbol{\Delta}$, occurrence records based on morphology and molecular evidence)

Star 1988), the morphological distinctions between these two species are not clear (Kobayasi 1967; Hamilton \& Edlund 1994), raising the question whether the two may be conspecific. More generally, additional sequence data will be needed to investigate if $P$. fluviatilis is a single, widely distributed species or comprised of several species.

P. stipitata Suhr ex Jessen and P. meridionalis Setchell \& Gardner, widely distributed in marine habitats of both hemispheres, are expected to be present whenever environmental conditions are suitable (Rindi et al. 2004, 2007; Heesch et al. 2012, 2016). Some other species, such as P. calophylla and those endemic freshwater species reported in China, appear to have more limited distributions. The different dispersal ability among species of Prasiola may thus be related to the type of habitat occupied, with terrestrial species generally having wider geographical ranges compared to aquatic species, especially submerged freshwater species (Heesch et al. 2016). P. fluviatilis, however, does not seem to perfectly conform to this view of restricted distribution. P. Aluviatilis has been recorded from Polar regions to lower latitudes in both hemispheres, where it is mostly located in very specialized glacier areas (Fig. 5). It was reported as a stenothermic cold water species, and we found that it disappeared in the section of the stream where the water temperature was more than $5^{\circ} \mathrm{C}$. P. fluviatilis thus apparently occupies a narrow ecological niche, while it shows a wide, though disjunct, geographical distribution. We acknowledge that these hypotheses are still speculative and more morphological, ecological and phylogenetic research of Prasiola is needed to understand the patterns and drivers of geographical distributions of species in various environments.

\section{Acknowledgements}

The authors are grateful to Fabio Rindi and two anonymous reviewers for useful comments that improved our manuscript. We thank Prof Bart Van de Vijver and Prof J. Patrick Kociolek for their help with this manuscript.

\section{REFERENCES}

Barinova S., Boboev M. \& Hisoriev H. 2015. — Freshwater algal diversity of the South-Tajik Depression in a high-mountainous extreme environment, Tajikistan. Turkish Journal of Botany 39: 535-546. http://doi.org/10.3906/bot-1406-45

Barinova S. \& NiYATBECOV T. 2018. - Alpha-biodiversity of nondiatom algae in the Pamir aquatic habitats, Tajikistan. Biodiversity International Journal 2: 236-263. http://doi.org/10.15406/ bij.2018.02.00065

BørGesen F. 1946. - Some marine algae from Mauritius. An additional list of species to Part 1. Chlorophyceae. Kongelige Danske Videnskabernes Selskab, Biologiske Meddelelser 20: 1-64.

BORGE O. 1934. - Schwedisch-Chinesische Wissenschaftliche Expedition nach den Nordwestlichen Provinzen Chiias. Under Leitung von Dr. Sven Hedin und Prof. Su Ping-chang. Algen gesammelt vom schwedischen arzt der expedition Dr. David Hummel 1927-1930. Archiv för Botanik 25A: 1-18.

Bringloe T. T., SjøTun K. \& SAunders G. W. 2019. — A DNA barcode survey of marine macroalgae from Bergen (Norway). Marine Biology Research 15 (10): 580-589. https://doi:10.1080 /17451000.2019.1699659

Bringloe T. T. \& SAunders G. W. 2019. - Trans-Arctic speciation of Florideophyceae (Rhodophyta) since the opening of the Bering Strait, with consideration of the "species pump" hypothesis. Journal of Biogeography 46 (4): 694-705. https://doi. org/10.1111/jbi.13504

Eaton A. E. 2012. - An Account of the Petrological, Botanical, and 
Zoological collection made in Kerguelen's Land and Rodriguez duting the transit of Venus expedition 1874-75. Cambridge University Press, Cambridge, $652 \mathrm{p}$.

ETTL H. \& GÄrTnER G. 1995. - Syllabus der Boden-, Luft- und Flechtenalgen. Gustav Fischer Verlag, Stuttgart, Jena, 721 p.

Famà P., Wysor B., Kooistra W. H. C. F. \& Zuccarello G. C. 2002. - Molecular phylogeny of the genus Caulerpa (Caulerpales, Chlorophyta) inferred from chloroplast tufA gene. Journal of Phycology 38 (5): 1040-1050. https://doi.org/10.1046/j.1529-8817.2002. t01-1-01237.x

FELSENSTEIN J. 1981. — Evolutionary trees from DNA sequences: A maximum likelihood approach. Journal of Molecular Evolution 17: 368-376. https://doi.org/10.1007/BF01734359

Garrido-Benavent I., Søchting U., De Los Ríos Murillo A. \& PÉREZ-OrTega S. 2016. - Shackletonia cryodesertorum (Teloschistaceae, Ascomycota), a new species from the McMurdo Dry Valleys (Antarctica) with notes on the biogeography of the genus Shackletonia. Mycological Progress 15 (7): 743-754. https:// doi.org/10.1007/s11557-016-1204-x

Garrido-BenaVEnt I., De Los Ríos A. FernándeZ-MEndoza F. \& PÉREZ-OrTEGA S. 2017a. — No need for stepping stones: Direct, joint dispersal of the lichen-forming fungus Mastodia tessellata (Ascomycota) and its photobiont explains their bipolar distribution. Journal of Biogeography 45 (1): 213-224. https://doi. org/10.1111/jbi.13105

Garrido-Benavent I., Pérez-Ortega S. \& De Los Ríos A. 2017b. - From Alaska to Antarctica: Species boundaries and genetic diversity of Prasiola (Trebouxiophyceae), a foliose chlorophyte associated with the bipolar lichen-forming fungus Mastodia tessellate. Molecular Phylogenetics and Evolution 107: 117-131. https://doi.org/10.1016/j.ympev.2016.10.013

GLIMS \& NSIDC 2005 [updated 2019]. — Global Land Ice Measurements from Space glacier database. Compiled and made available by the international GLIMS community and the National Snow and Ice Data Center, Boulder CO, U.S.A.

Guindon S. \& GASCUEL O. 2003. - A simple, fast, and accurate algorithm to estimate large phylogenies by maximum likelihood. Systematic Biology 52 (5): 696-704. https://doi. org/10.1080/10635150390235520

GuirY M. D. \& Guiry G. M. 2020. — AlgaeBase. World-wide electronic publication, National University of Ireland, Galway. Available from: http://www.algaebase.org [accessed 3 July 2020].

HaLl T. A. 1999. - BioEdit: a user-friendly biological sequence alignment editor and analysis program for Windows 95/98/NT. Nucleic Acids Symposium Series 41: 95-98.

Hall J. D., Fučíková K., Lo C., LeWis L. A. \& Karol K. G. 2010. - An assessment of proposed DNA barcodes in freshwater green algae. Cryptogamie, Algologie 31 (4): 529-555.

Hamilton B. P. \& EdLund S. A. 1994. - Occurrence of Prasiola Aluviatilis (Chlorophyta) on Ellesmere Island in the Canadian Arctic. Journal of Phycology 30: 217-221. https://doi.org/10.1111/ j.0022-3646.1994.00217.x

Hartmann A., Holzinger A., GanZera M. \& Karsten U. 2016. Prasiolin, a new UV-sunscreen compound in the terrestrial green macroalga Prasiola calophylla (Carmichael ex Greville) Kützing (Trebouxiophyceae, Chlorophyta). Planta 243: 161-169. https:// doi.org/10.1007/s00425-015-2396-z

Heesch S., Sutherland J. E. \& Nelson W. A. 2012. - Marine Prasiolales (Trebouxiophyceae, Chlorophyta) from New Zealand and the Balleny Islands, with descriptions of Prasiola novaezelandiae sp. nov. and Rosenvingiella australis sp. nov. Phycologia 51 (2): 217-227. https://doi.org/10.2216/10-95.1

Heesch S., Pažoutová M., Moniz M. B. J. \& Rindi F. 2016. Prasiolales (Trebouxiophyceae, Chlorophyta) of the Svalbard Archipelago: diversity, biogeography and description of the new genera Prasionella and Prasionema. European Journal of Phycology 51: 171-187. https://doi.org/10.1080/09670262.2015.1115557

Hu H. \& WeI Y. 2006. - The Freshwater Algae of China. Systemat- ics, Taxonomy and Ecology. Science Press, Beijing, 1023 p.

JaO C.-C. 1947. - Prasiola yunnanica, sp. nov. Botanical Bulletin of Academia Sinica 1 (2): 110.

John D. M. 2002. — Order Prasiolales, in JoHN D. M., WHIT TON B. A. \& BROOK A. J. (eds), The Freshwater Algal Flora of the British Isles. Cambridge University Press, Cambridge: 433-468.

Kim M. S., Jun M.-S., KIM C. A., YonG J., Kim J. H. \& CHO G. Y. 2015. - Morphology and phylogenetic position of a freshwater Prasiola species (Prasiolales, Chlorophyta) in Korea. Algae 30 (3) 197-205. https://doi.org/10.4490/algae.2015.30.3.197

KlochKova T. A., KlochKova N. G. \& Kim G. H. 2017. Molecular Phylogeny of the Marine Prasiola and Rosenvingiella Species (Chlorophyta: Prasiolales) from Southeastern Kamchatka. Russian Journal of Marine Biology 43 (1): 34-41. https://doi. org/10.1134/s1063074017010060

KNebel G. 1935. - Monographie der Algenreihe der Prasiolales, insbesondere von Prasiola crispa. Hedwigia 75: 1-120.

Kobayasi Y. 1967. - Prasiola crispa and its allies in the Alaskan Arctic and Antarctica. Bulletin of the National Science Museum Tokyo 10: 209-219.

Kornmann P. \& SAHLing P. H. 1974. - Prasiolales (Chlorophyta) von Helgoland. Helgol. Meeresunters 26: 99-133. https://doi. org/10.1007/bf01611379

KovÁčik L. \& Pereira A. B. 2001. - Green alga Prasiola crispa and its lichenized form Mastodia tesselata in Antarctic environment: general aspects. Nova Hedwigia Beiheft 123: 465-478

Lagersted N. G. W. 1869. - Om algslägtet Prasiola. Försök till en Monographi. Akademisk Afhandling, Uppsala University: 1-42.

LOKHORST G. M. \& STAR W. 1988. - Prasiola velutina (Lyngbye) Wille in the Netherlands. Archiv für Hydrobiologie, Supplement 78: 313-327.

Matuła J., Pietryka M., Richter D. \& Wojtuń B. 2007. Cyanoprokaryota and algae of Arctic terrestrial ecosystems in the Hornsund area, Spitsbergen. Polish Polar Research 28 (4): 283-315.

McClintic A. S., CasamatTa D. A. \& Vis M. L. 2003. - A survey of algae from montane cloud forest and alpine streams in Bolivia: macroalgae and associated microalgae. Nova Hedwigia 76: 363-379. https://doi.org/10.1127/0029-5035/2003/0076-0363

MENEGHINI G. 1838. - Cenni sulla organographia e fisiologia delle alghe. Nuovi Saggi della [Cesarea] Regia Accademia di Scienze, Lettere ed Arti di Padova 4: 325-388.

Moniz M. B. J., Rindi F. \& Guiry M. D. 2012a. - Phylogeny and taxonomy of Prasiolales (Trebouxiophyceae, Chlorophyta) from Tasmania, including Rosenvingiella tasmanica sp. nov. Phycologia 51 (1): 86-97. https://doi.org/10.2216/10-103.1

Moniz M. B. J., Rindi F., NOvis P. M., Broady P. A. \& Guiry M. D. 2012b. - Molecular phylogeny of Antarctic Prasiola (Prasiolales, Trebouxiophyceae) reveals extensive cryptic diversity. Journal of Phycology 48: 940-955. https://doi.org/10.1111/j.15298817.2012.01172.x

Moniz M. B. J., Guiry M. D. \& Rindi F. 2014. - tufA phylogeny and species boundaries in the green algal order Prasiolales (Trebouxiophyceae, Chlorophyta). Phycologia 53 (4): 396-406. https://doi.org/10.2216/13-233.1

NAW M. W. D. \& Hara Y. 2002. - Morphology and molecular phylogeny of Prasiola sp. (Prasiolales, Chlorophyta) from Myanmar. Phycological Research 50: 175-182. https://doi. org/10.1111/j.1440-1835.2002.tb00149.x

NeuSTUPa J. 1998. - Prasiola crispa (Lightfoot) Meneghini in Královská obora in Prague. Novitates Botanicae Universitatis Carolinae 12: 35-39.

PosAdA D. \& BuCKLEY T. R. 2004. - Model selection and model averaging in phylogenetics: advantages of Akaike information criterion and Bayesian approaches over likelihood ratio tests. Systematic Biology 53 (5): 793-808. https://doi. org/10.1080/10635150490522304

PRINTZ H. 1964. — Die Chaetophoralen der Binnengewässer. Eine systematische Übersicht. Hydrobiologia 24: 1-376. https://doi. 
org/10.1007/bf00170411

RejMent-Grochowska I. 1952. - A new station of Prasiola fluviatilis (Sommerf.) Aresch. in the Tatra Mountains. Acta Societatis Botanicorum Poloniae 21: 435-441.

Richter D., MatuŁa J., Urbaniak J., Waleron M. \& CZerwiKMARCINKOWSKA J. 2017. - Molecular, morphological and ultrastructural characteristics of Prasiola crispa (Lightfoot) Kützing (Chlorophyta) from Spitsbergen (Arctic). Polar Biology 40: 379-397. https://doi.org/10.1007/s00300-016-1966-2

Rindi F. 2007 - Prasiolales, in Brodie J., Maggs C. A. \& JoHn D. M. (eds), Green Seaweeds of Britain and Ireland. British Phycological Society, Dunmurry: 13-31.

RINDI F. 2010. - Reproduction and life history of the green alga Prasiola linearis Jao (Trebouxiophyceae, Chlorophyta). Botanica Marina 53: 1-7. https://doi.org/10.1515/bot.2010.002

Rindi F. \& GUIRY M. D. 2004. - Composition and spatial variability of terrestrial algae assemblages occurring at the bases of urban walls in Europe. Phycologia 43 (3): 225-235. https://doi. org/10.2216/i0031-8884-43-3-225.1

Rindi F., Guiry M. D., Barbiero R. P. \& Cinelli F. 1999. The marine and terrestrial Prasiolales (Chlorophyta) of Galway City, Ireland: a morphological and ecological study. Journal of Phycology 35: 469-482. https://doi.org/10.1046/j.15298817.1999.3530469.x

Rindi F., McIvor L. \& Guiry M. D. 2004. — The Prasiolales (Chlorophyta) of Atlantic Europe: an assessment based on morphological, molecular, and ecological data, including the characterization of Rosenvingiella radicans (Kützing) comb. nov. Journal of Phycology 40: 977-997. https://doi.org/10.1111/j.15298817.2004.04012.x

Rindi F., McIvor L., SHerwood A. R., FriedL T., Guiry M. D. \& SHEATH R. G. 2007. - Molecular phylogeny of the green algal order Prasiolales (Trebouxiophyceae, Chlorophyta). Journal of Phycology 43: 811-822. https://doi.org/10.1111/j.15298817.2007.00372.x

Rodríguez R. R. \& Jiménez J. C. 2005. - Taxonomy and distribution of freshwater Prasiola (Prasiolales, Chlorophyta) in central Mexico. Cryptogamie, Algologie 26 (2): 177-188. https:// doi.org/10.1007/s10452-006-9068-9

Rodríguez R. R., Jiménez J. C. \& Delgado C. M. 2007. Microhabitat and morphometric variation in two species of Prasiola (Prasiolales, Chlorophyta) from streams in Central
Mexico. Aquatic Ecology 41: 161-168. https://doi.org/10.1007/ s10452-006-9068-9

RonQuist F. \& HuelsenbeCK J. P. 2003. - MrBayes 3: Bayesian phylogenetic inference under mixed models. Bioinformatics 19 (12): 1572-1574. https://doi.org/10.1093/bioinformatics/btg180 SAUNDERS G. W. \& KUCERA H. 2010. - An evaluation of $r b c \mathrm{~L}$, tufA, UPA, LSU and ITS as DNA barcode markers for the marine green macroalgae. Cryptogamie, Algologie 31: 487-528.

SETCHELL W. A. \& GARDNER N. L. 1903. - Algae of northwestern America. University of California Publications in Botany 1: 165-419.

SetChell W. A. \& Gardner N. L. 1920. — The marine algae of the Pacific coast of North America. Part II. Chlorophyceae. University of California Publications in Botany 8: 139-374.

Sherwood A. R., Garbary D. J. \& SHeATH R. G. 2000. - Assessing the phylogenetic position of the Prasiolales (Chlorophyta) using $r b c \mathrm{~L}$ and $18 \mathrm{~S}$ rRNA gene sequence data. Phycologia 39 (2): 139-146. https://doi.org/10.2216/i0031-8884-39-2-139.1

SOMMERFELT S. C. 1828. - Bemaerkninger paa en botanisk Excursion til Bergens Stift. Magazin for Naturvidenskaberne 9: 1-33.

Sutherland J. E., Miyata M., Ishikawa M. \& Nelson W. A. 2016. - Prasiola (Prasiolales, Trebouxiophyceae) in Japan: a survey of freshwater populations and new records of marine taxa. Phycological Research 64: 110-117. https://doi.org/10.1111/pre.12124

TAYLOR W. R. 1928. - Alpine algal flora of the mountains of British Columbia. Ecology 9: 343-348.

Thompson J. D., Gibson T. J., Plewniak F., Jeanmougin F. \& HigGins D. G. 1997. — The CLUSTAL_X Windows Interface: Flexible Strategies for Multiple Sequence Alignment Aided by Quality Analysis Tools. Nucleic Acids Research 25 (24): 48764882. https://doi.org/10.1093/nar/25.24.4876

Thüs H., Mggia L., Pérez-Ortega S., Favero-Longo S. E., Joneson S., O’Brien H., Nelsen M. P., Dugue-Thüs R., Grube M., Friedl T., Brodie J., ANdrew C. J., LÜCKING R., LUTZONI F. \& GUIDAN C. 2011. - Revisiting photobiont diversity in the lichen family Verrucariaceae (Ascomycota). European Journal of Phycology 46 (4): 399-415. https://doi:10.1080/096 70262.2011.629788

VAZQuez M. R. \& URiza E. A. C. 2003. - Flora algal de ríos templados en la zona occidental de la cuenca del Valle de México. Anales del Instituto de Biología 74: 143-194.

WAERN M. 1952. - Rocky-shore algae in the Öregrund Archipelago. Acta Phytogeographica Suecica 30:1-298. 


\section{APPENDICES}

APPENDIX 1. - Relevant $r b c L$ sequence information downloaded from GenBank in this study.

\begin{tabular}{|c|c|c|c|c|}
\hline species & rbcL & country & continent & citation \\
\hline Prasiola antarctica Kützing & JQ669721 & Palmer Station & Europe & Moniz et al. (2012b) \\
\hline P. borealis M.Reed & EF203021 & Canada & North America & Rindi et al. (2007) \\
\hline P. borealis & JF949724 & Australia & Oceania & Moniz et al. (2012a) \\
\hline P. calophylla (Carmichael ex Greville) Kützing & AY694194 & Ireland & Europe & Rindi et al. (2004) \\
\hline P. calophylla & EF589145 & New Zealand & Oceania & Novis (2007) \\
\hline P. calophylla & JQ669726 & Ireland & Europe & Moniz et al. (2012) \\
\hline P. calophylla & KX443662 & Austria & Europe & Hartmann et al. (2016) \\
\hline P. cf. calophylla & KT354051 & Japan & Asia & Sutherland et al. (2016) \\
\hline P. crispa (Lightfoot) Kützing & HQ174307 & Balleny Islands & Antarctica & Heesch et al. (2012) \\
\hline P. crispa & JQ669723 & King George IsI & Antarctica & Moniz et al. (2012b) \\
\hline P. crispa & JQ669707 & Marshall Val. & Antarctica & Moniz et al. (2012) \\
\hline P. crispa & LN877820 & Norway & Europe & Heesch et al. (2016) \\
\hline P. crispa & JQ669714 & Norway & Europe & Moniz et al. (2012) \\
\hline P. delicata Setchell \& N.L.Gardner & EF203020 & Canada & North America & Rindi et al. (2007) \\
\hline P. delicata & KT354050 & Japan & Asia & Sutherland et al. (2016) \\
\hline P. fluviatilis (Sommerfelt) Areschoug ex Lagerstedt & AF189063 & Canada & North America & Sherwood et al. (2000) \\
\hline$P$. fluviatilis & LN877822 & Norway & Europe & Heesch et al. (2016) \\
\hline P. furfuracea (Mertens ex Hornemann) Trevisan & AF189064 & Scotland & Europe & Sherwood et al. (2000) \\
\hline P. furfuracea & LN877823 & Norway & Europe & Heesch et al. (2016) \\
\hline P. japonica Yatabe & KT354068 & Nepal & Asia & Sutherland et al. (2016) \\
\hline$P$. linearis Jao & AF189065 & Canada & North America & Sherwood et al. (2000) \\
\hline P. linearis & EF203017 & United States & North America & Rindi et al. (2007) \\
\hline P. meridionalis Setchell \& Gardner & AY694191 & United States & North America & Rindi et al. (2004) \\
\hline P. mexicana Agardh & JQ669719 & Mexico & North America & Moniz et al. (2012) \\
\hline P. novaezelandiae S.Heesch \& W.A.Nelson & HQ174306 & New Zealand & Oceania & Heesch et al. (2012) \\
\hline P. stipitata Suhr ex Jessen & JQ669729 & Canada & North America & Moniz et al. (2012) \\
\hline$P$ stipitata & HQ174308 & New Zealand & Oceania & Heesch et al. (2012) \\
\hline P. sp. & JQ669710 & Garwood Val. & Antarctica & Moniz et al. (2012) \\
\hline P. sp. & JN573837 & Chile & South America & Thüs et al. (2011) \\
\hline P. sp. & AY694197 & England & Europe & Rindi et al. (2004) \\
\hline P. sp. & MF882983 & King George Island & Antarctica & Garrido-Benavent et al. (2017a) \\
\hline P. sp. & AF387111 & New Zealand & Oceania & Woolcott \& King (2001) \\
\hline P. yunnanica Jao & JQ669708 & China & Asia & Moniz et al. (2012) \\
\hline
\end{tabular}

APPENDIX 2. - Relevant tufA sequence information downloaded from GenBank in this study.

\begin{tabular}{|c|c|c|c|c|}
\hline species & tufA & country & continent & citation \\
\hline Prasiola antarctica Kützing & KF993447 & Palmer Station & Antarctica & Moniz et al. (2014) \\
\hline P. borealis M.Reed & KF993448 & Canada & North America & Moniz et al. (2014) \\
\hline P. borealis & KY028887 & United States & North America & Garrido-Benavent et al. (2016) \\
\hline P. calophylla (Carmichael ex Greville) Kützing & KF993455 & Ireland & Europe & Moniz et al. (2014) \\
\hline P. calophylla & KF993449 & Ireland & Europe & Moniz et al. (2014) \\
\hline P. calophylla & MH571168 & United States & North America & Bringloe \& Saunders (2019) \\
\hline P. crispa (Lightfoot) Kützing & LN877821 & Norway & Europe & Heesch et al. (2016) \\
\hline P. delicata Setchell \& N.L.Gardner & KY029020 & United States & North America & Garrido-Benavent et al. (2017a) \\
\hline P. furfuracea (Mertens ex Hornemann) Trevisan & LN877826 & Norway & Europe & Heesch et al. (2016) \\
\hline P. japonica Yatabe & KR261682 & Japan & Asia & Kim et al. (2015) \\
\hline P. meridionalis Setchell \& Gardner & KF993444 & United States & North America & Moniz et al. (2014) \\
\hline P. meridionalis & KF993434 & United States & North America & Moniz et al. (2014) \\
\hline P. novaezelandiae S.Heesch \& W.A.Nelson & KF993440 & New Zealand & Oceania & Moniz et al. (2014) \\
\hline P. stipitata Suhr ex Jessen & KF993460 & Canada & North America & Moniz et al. (2014) \\
\hline P. sp. & HQ610263 & Canada & North America & Saunders \& Kucera (2010) \\
\hline P. sp. & KY028982 & Greenwich Island & Antarctica & Garrido-Benavent et al. (2017a) \\
\hline P. yunnanica Jao & KF993445 & China & Asia & Moniz et al. (2014) \\
\hline
\end{tabular}


APPENDIX 3. - Uncorrected pairwise distances between $r b c L$ sequences of the taxa in this study.

\begin{tabular}{|c|c|c|c|c|c|c|c|c|c|c|c|c|c|c|c|c|}
\hline Taxon & No. & & 2 & 3 & 4 & 5 & 6 & 7 & 8 & 9 & 10 & 11 & 12 & 13 & 14 & 15 \\
\hline MT846163 & 1 & & & & & & & & & & & & & & & \\
\hline Prasiola fluviatilis & & & & & & & & & & & & & & & & \\
\hline AF189063 & 2 & 0.003 & & & & & & & & & & & & & & \\
\hline P. fluviatilis & & & & & & & & & & & & & & & & \\
\hline $\begin{array}{l}\text { LN877822 } \\
\text { P. fluviatilis }\end{array}$ & 3 & 0.003 & B 0.000 & & & & & & & & & & & & & \\
\hline $\begin{array}{l}\text { JQ669721 } \\
\text { P. antarctica }\end{array}$ & 4 & 0.049 & 90.049 & 0.049 & & & & & & & & & & & & \\
\hline EF203021 & 5 & 0.042 & 0.042 & 0.042 & 0.016 & & & & & & & & & & & \\
\hline $\begin{array}{l}\text { P. borealis } \\
\text { JQ669726 }\end{array}$ & 6 & 0.015 & 0.018 & 0.018 & 30.039 & 0.036 & & & & & & & & & & \\
\hline $\begin{array}{l}\text { P. calophylla } \\
\text { HQ174307 }\end{array}$ & 7 & 0.049 & 0.049 & 0.049 & 0.024 & 0.015 & 0.043 & & & & & & & & & \\
\hline P. crispa & & & & & & & & & & & & & & & & \\
\hline $\begin{array}{l}\text { EF203020 } \\
\text { P. delicata }\end{array}$ & 8 & 0.039 & 9.041 & 0.041 & 10.035 & 0.031 & 0.027 & 70.038 & & & & & & & & \\
\hline $\begin{array}{l}\text { AF189064 } \\
\text { P. furfuracea }\end{array}$ & 9 & 0.032 & 0.035 & 0.035 & 50.038 & 0.031 & 0.023 & B 0.041 & 0.014 & & & & & & & \\
\hline $\begin{array}{l}\text { KT354068 } \\
\text { P. japonica }\end{array}$ & 10 & 0.031 & 0.032 & 0.032 & 0.032 & 0.034 & 0.024 & 40.041 & 0.034 & 0.028 & & & & & & \\
\hline $\begin{array}{l}\text { AY694191 } \\
\text { P. meridionalis }\end{array}$ & 11 & 0.032 & 0.035 & 0.035 & 50.038 & 0.031 & 0.023 & 30.041 & 0.014 & 0.000 & 0.028 & & & & & \\
\hline $\begin{array}{l}\text { JQ669719 } \\
\text { P. mexicana }\end{array}$ & 12 & 0.054 & 40.054 & 0.054 & 40.030 & 0.023 & 0.046 & 0.024 & 0.038 & 0.043 & 0.041 & 0.043 & & & & \\
\hline HQ174306 & 13 & 0.049 & 9.049 & 0.049 & 9.023 & 0.009 & 0.043 & 30.018 & 0.038 & 0.038 & 0.038 & 0.038 & 0.024 & & & \\
\hline $\begin{array}{l}\text { P. novaezelandiae } \\
\text { AF189065 } \\
\text { P. linearis }\end{array}$ & 14 & 0.032 & 0.035 & 0.035 & 0.038 & 0.031 & 0.023 & 30.041 & 0.014 & 0.000 & 0.028 & 0.000 & 0.043 & 0.038 & & \\
\hline $\begin{array}{l}\text { JQ669729 } \\
\text { P. stipitata }\end{array}$ & 15 & 0.032 & 0.035 & 0.035 & 50.038 & 0.031 & 0.023 & 30.041 & 0.014 & 0.000 & 0.028 & 0.000 & 0.043 & 0.038 & 0.000 & \\
\hline $\begin{array}{l}\text { JQ669708 } \\
\text { P. yunnanica }\end{array}$ & 16 & 0.031 & 0.032 & 0.032 & 0.032 & 0.034 & 0.024 & 40.041 & 0.034 & 0.028 & 0.000 & 0.028 & 0.041 & 0.038 & 0.028 & 0.028 \\
\hline
\end{tabular}

APPENDIX 4. - Substitution models inferred for each gene sequence alignment based on Modeltest 3.7 analysis.

\begin{tabular}{|c|c|c|c|}
\hline Molecular marker & Model selected & Base frequency & Rate matrix \\
\hline$r b c L$ & $\begin{aligned} \operatorname{TrN} & +\mathrm{I}+\mathrm{G} \\
-\ln \mathrm{L} & =2430.4280 \\
\mathrm{~K} & =7 \\
(\mathrm{I}) & =0.6195 \\
(\mathrm{G}) & =0.5950 \\
& -\end{aligned}$ & $\begin{aligned} \text { freqA } & =0.3001 \\
\text { freq } C & =0.1576 \\
\text { freqG } & =0.2107 \\
\text { freq } T & =0.3316 \\
& - \\
& -\end{aligned}$ & $\begin{aligned} \mathrm{R}(\mathrm{a})[\mathrm{A}-\mathrm{C}] & =1.0000 \\
\mathrm{R}(\mathrm{b})[\mathrm{A}-\mathrm{G}] & =5.8833 \\
\mathrm{R}(\mathrm{c})[\mathrm{A}-\mathrm{T}] & =1.0000 \\
\mathrm{R}(\mathrm{d})[\mathrm{C}-\mathrm{G}] & =1.0000 \\
\mathrm{R}(\mathrm{e})[\mathrm{C}-\mathrm{T}] & =7.9502 \\
\mathrm{R}(\mathrm{f})[\mathrm{G}-\mathrm{T}] & =1.0000\end{aligned}$ \\
\hline tufA & $\begin{aligned} \text { GTR+I+G } \\
-\operatorname{lnL}=2203.2332 \\
\mathrm{~K}=10 \\
(\mathrm{I})=0.4296 \\
(\mathrm{G})=0.5266 \\
-\end{aligned}$ & $\begin{aligned} \text { freqA } & =0.3704 \\
\text { freqC } & =0.1241 \\
\text { freqG } & =0.2166 \\
\text { freqT } & =0.2889 \\
& - \\
& -\end{aligned}$ & $\begin{aligned} \mathrm{R}(\mathrm{a})[\mathrm{A}-\mathrm{C}] & =2.8417 \\
\mathrm{R}(\mathrm{b})[\mathrm{A}-\mathrm{G}] & =3.7130 \\
\mathrm{R}(\mathrm{c})[\mathrm{A}-\mathrm{T}] & =0.3758 \\
\mathrm{R}(\mathrm{d})[\mathrm{C}-\mathrm{G}] & =0.6766 \\
\mathrm{R}(\mathrm{e})[\mathrm{C}-\mathrm{T}] & =7.9474 \\
\mathrm{R}(\mathrm{f})[\mathrm{G}-\mathrm{T}] & =1.0000\end{aligned}$ \\
\hline
\end{tabular}

